\title{
History Pain and Pain Management
}

\author{
Gugsa Nemera Germossa* \\ Department of Nursing, Ethiopia \\ *Corresponding author: Gugsa Nemera Germossa, Department of Nursing, Ethiopia
}

Submission: 韭December 15, 2017; Published: 眥 February 13, 2018

\section{Introduction}

Pain is a complex medical problem and universal physical affiliation of mankind. The existing evidence shows pain defined human suffering in history. It is the most pervasive and universal form of human distress. It is believed that, pain contribution to poor quality of life is very high. The management of pain has also been modified throughout the history of mankind [1-3].

Since the existence of humankind on our planet, millions of years before today, countless number of people died in pain. Society evolved from primitive to post modernization; in fact there are people who live in primitive like style in our world. Medical technology advanced, pharmacological industry expanded, and health infrastructure increased. But as of today still millions lives with pain and dies in pain $[2,3]$. Why? What are the trends in pain concept and its management shows?

\section{Antiquity}

\section{Pain as a manifestation and disease in it self}

Antiquity is the period of the ancient past before middle age, i.e. before 5 th century. Homer (12th-8th century BC), Hippocrates (430-380 BC), Erasistratus (3rd century BC) and Celsus (1st century AD) work during this period was influential on how pain believed, perceived and treated. Understanding of pain in this period varies from century to century. Some believed it as emotional and the other believed as sensational aspect of life [4].

Homer's, an ancient Greek legendary author of the Iliad and Odyssey, perceived pain as how the subject engrossed in pain with respect to time of mourning and its rituals, grief, worry, violent emotion and child birth. A sufferer of such condition was treated by Homer's plant [4].

Hippocrates (430-380 BC) is a Greek physician considered the most outstanding figure in history of medicine. In his work Hippocrates collections described pain as a word rooted from "adune" which means consuming, grief, pain and sorrow. According to him, it is caused by disturbance of the four body humor's (blood, phlegm, yellow bile and black). He believed that pain was the major focus of interaction between patient and providers. "Like with like" was the philosophical thinking of his time. And therefore he believed that pain should be treated with pain. Thus, Hippocrates used cauterization by unbleached Linen (this kind of treatment still used in parts of Ethiopian rural area), praying and narcotic plants for gynecological pain (Mandrake, Henbane, Nightshades and Poppies [4].

In the Third century before Christ, there was an influence of Alexandria. It was time of extensive experimentation and anatomical discoveries of arteries, veins, brain, pulse, and nerves by Herophilus and Erasistratus. During this time pain was perceived as invader of inner organ and cannot be restored to integrity without knowing its structure. This thought leads to opening of cadaver and live experimentation. Criminals were subjected to this live experimentation [4].

In the time of Roman Empire, Celsus (1st century), Aretaeus of Cappadocia (lived around 1st century) and Galen of Pergamum (130AD-210AD) were some of dominant Greek physician. During this time, pain was seen as a disease in itself and classified into different forms. Celsus believed pain as a disease in itself which is similar to the 21st century of chronic pain labeling. Celsus recommended rest, exercise, bloodletting, incision into skin and application of resin plaster and hot food. The treatment varies according to the stage of the disease i.e. pain. At the beginning treatment started with bloodletting and exercise comes in the later stages [4].

Aretaeus of Cappadocia believed that pain caused by cold and dry together. His work related to pain was classification of pain, particularly headache. The management approach to pain was similar to Celsus approach. According to him, pain was treated by bloodletting, washing with hot water, wet cupping and cauterization by branding iron (stillin use some part of Ethiopia) and rubbing with rube facient herbal plants [4].

Galen of Pergamum idea influenced pain science until to the beginning of renascence. He introduced animal (Pig, Monkey, cattle's) experimentation. This the first time in history where the idea that pain is not only human domain introduced. As a result he discriminated motor and sensory nerves on the bases of tender and hard nerves. According to Galen, tender nerve was apt for experiencing impression while hard nerve for acting. From this ground, he classified pain as a component of touch (tactile sensation). For him pain was caused by internal disruption and 
external aggression. And therefore should be understood as feeling of sensation and sign of inflammation. He classified pain into four different forms: Pulsetic, gravitive, tenssive and pungitive pain. This classification of pain virtually handed down to modern times as throbbing, weighty, stretching, and lacerating respectively [4].

In the very early days, the ancient philosophers Plato and his student Aristotle consider pain as emotional experience centered in human heart. They believed pain as independent being external to human heart and invade the body as sprite through injury. This thought is persistent in which pain often seen as God (gods') punishment or test of faith. Aristotle does not include sense of pain in his five senses. Aristotle's and Plato placed pain with pleasure among the passion of the soul The word pain itself derived from the Latin word "poena" meaning penalty or punishment. Unfortunately, pain still carries that connotation $[4,5]$.

\section{Religion and pain}

Religion also influenced belief about pain in ancient cultures. At that times pain other than injury believed to be caused by gods influence or spirits of death entered into body through ear and nose. God as a cause and relief of pain written in many part of holly bible [1]. For example incurable pain due to great guilt and flagrant sin (, the cause and re pain described as Gods punishment (Jeremiah 30.15), multiplication of women's pain in childbearing (Genesis 3:16), painful crucification of Christ on cross (Mark 15:24), the suffering of Job with sore boils from the sole of his foot onto his head to affirm his faith to God (Job2:7) and relief for pain and healing from God as ...."Deaths shall be no more; neither shall there be mourning nor crying nor pain" (Revelation 31:4). Bearing pain and mourning were considered as practice in the healing comfort of God as Christ, Maria, Job or the martyrs had demonstrated [6].

The holy Quran also states about pain as "Those who reject our signs, we shall cast into the fire; as often as their skins are roasted through. We shall change them for fresh skins, that they may taste the punishment; for Allah is Exalted in power; Wise." (4:56).Allah did not say "as often as their skins are burned", as burning could be partial, but He rather said: "as often as their skins are roasted through", i.e., totally burned with all nerves of sensation and pain. So, He the Almighty associated between the sensation of pain and the skin when roasted and burned totally, thus losing its structure and function. When sensation of pain is lost, a new fully composed and functional skin is replaced, where the nerve ending responsible for the painful sensation of heat and burn perform and function to make the unbeliever taste the punishment of being burned with fire over and over again [7].

\section{Midleage (5th -15th Century)}

\section{Pain as a form of divine retribution/ punishment}

The predominant events of this time was internal chaos to roman empire, opposite attitude between east and west, Syria and Persia growth, doing opposite act and the transfer of medical knowledge from orient to Occident. The Christian belief about pain was remaining dominant. Avicenna (980-1037 AD), the most significant Persian physician, believed that pain is feeling of contradictory quality. It should also be recognized that Galen said that there must be broke or cut, stretch abraded skin to feel pain. The idea of removing sensibility of the part introduced, thus surgery was one method of pain treatment. Opium, mandragora root, nightshade, Henbane and poppy in the form of suppository, eye wash were used to treat pain during this time while saffron, myrrh and castor oil can be added [1,3,4].

\section{Renaissance to Present}

\section{Pain theories, drugs, guidelines and associations}

During the renascence period, Rene Descartes (1596-1650) refuted the idea that pain come from outside and proposed it as internal mechanical process. For him pain sensation occurs due to disturbance within the machine (body) and passed through nerves to the brain the brain. The concept of pain gradually shaped over time. Just over a century after Rene Descartes, due to the advancement of experimental science, four major theories of pain developed: specificity theory, intensity theory, pattern theory and gate control theory. All of the four competing theories accepted, pain as sensation due to stimuli and its path ways to brain, but they differ by the amount and type of stimuli that produce pain and its modulation [1-4,7].

According to specificity theory, nociceptors have thresholds at or nearer noxious level of the stimuli and each stimulus have specific connections to spinal and brainstem projection neuron. Whereas intensity coded afferent neuron that transduce innocuous and noxious stimulus which activate a neurons with wide dynamic range (WDR) was proposed by intensity theory. On the other hand pattern theory proposes extensive range of responses by somatic senses with differing relationship to intensity. Gate control theory prepossesses the level of sensation depends on the balance between the large (A-fibers) and the thin C-fiber) afferent fibers [7,8].

In May 1973, International association for study of pain (IASP) by University of Washington anesthesiology professor John J Bonica with purpose of having professional organization dedicated to pain research and management. Since then the organization supports research, patient care and education about pain throughout the world [7]. More recently pain nature and type understood by its characteristics of pain. Pain classified based on origin (somatic or visceral), duration (acute or chronic), mechanism (nociceptive or neuropathic), situation (incident, breakthrough and procedural pain [9].

The past understanding of pain and its management in one way or another influenced the current approach to pain management. Continuous efforts had been made to improve the current patient pain management. The development of opioids regulations, comprehensive and specific guidelines and unit or institution based polices and biological, psychological and environmental factor researches were some to mention $[1,8]$.

The advancement made about pain brought two compiling definition of pain which currently used in research and clinical 
care. International Association for the Study of Pain defines pain as an unpleasant sensory and emotional experience associated with actual or potential tissue damage [7]. Currently this definition guides pain research and practices. On the other hand, Mccaffery (1968) defined pain as" whatever the experiencing patient says it is, existing whenever the experiencing it does" [9]. This definition indicates the subjective nature of pain and it guides clinical care and patient provider interactions. From these two definitions we can understand the three dimension of pain: sensory, emotional and cognitive experience that can only be measured subjectively.

The current development and evidences on pain indicates pain should be considered as vital sign and right of the patient to be treated. The American Pain Society coined the phrase "Pain: The 5th Vital Sign" to emphasize the significance of effective pain management. Calling pain the fifth vital sign suggests that the pain assessment should be as automatic as taking traditional vital signs [10]. The JCAHO's (Joint Commission on the Accreditation of Healthcare Organizations, 2003) stressed that "pain is assessed in all patients" and that "patients have the right to appropriate assessment and management of pain" [11].

The role nurse in pain management have been grown since $1859 \mathrm{AD}$ and become vital currently. Nurses are the essential in diagnosing and treatment of pain in all facility. They are closest to patients and provide constant physical, emotional, spiritual and personal support. They play an important role in pain assessment, monitoring of patient response to treatment and keeping documents.

\section{Conclusion}

The current understanding and management of pain influenced in one way or another by historical events in the development of pain theories and therapies/remedies. Since when human being start to live on the earth, understanding about Pain concept defer by scholars which resulted in scientific arguments. This consequently

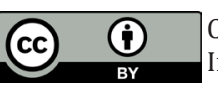

Creative Commons Attribution 4.0

nternational License

For possible submission use the below is the URL led to remarkable theoretical physiological, psychological and pharmacological advancements in pain.

The advancement in pain management varied along with historical conceptual understanding of pain. The diverse methods of pain management historically includes but not limited to praying, use of herbals, massages, use of anesthetic agent (ether, chloroform, nitrous oxide/laughing gas) during surgery, opioids, NSAID (NonSteroidal Anti Inflammatory Drugs), surgical (nerve block), TCENS (trans-coetaneous nerve stimulation) .More comprehensively, pain management can be categorized as traditional or modern and pharmacological or non-pharmacological/alternative medicine pain management.

\section{References}

1. Meldrum ML (2003) A capsule history of pain management. Jama 290(18): 2470-2475.

2. Hadjistavropoulos T, Craig KD (2004) Pain: psychological perspectives. In: Hadjistavropoulos T, Craig KD [Eds.] Psychology Press, UK.

3. Sabatowski R, Schafer D, Kasper SM, Brunsch H, Radbruch L, et al. (2004) Pain treatment: a historical overview. Curr Pharm Des 10(7): 701-716.

4. Rey R (1995) The history of pain. Transilated by louise Elliott Wallace. In: JA Cadden, SW Cadden [Eds.] Harvard university press. Cambridge, mass acheusetts, London, 102(2): 421-422.

5. Bible (1996) New International Version. The Holy Bible: new international version. Hodder \&Stoughton.

6. Ali MM (2011) HolyQuran. AhmadiyyaAnjumanIshaat Islam Lahore, USA.

7. Merskey H, Loeser JD, Dubner R (1975-2005) The paths of pain.

8. Dallenbach KM (1939) Pain: history and present status. The American Journal of Psychology 52(3): 331-347.

9. FMOH (2007) Pain management guideline.

10. American Chronic Pain Association (2015) Guide to Chronic Pain Medication \& Treatment.

11. Walid SN, Donahue NS, Dana M, Hyer LA, Robinson JS, et al. (2008) The Fifth Vital Sign-What Does It Mean? PainPractice 8(6): 417-422.

\section{Your subsequent submission with Crimson Publishers} will attain the below benefits

- High-level peer review and editorial services

- Freely accessible online immediately upon publication

- Authors retain the copyright to their work

- Licensing it under a Creative Commons license

- Visibility through different online platforms

- Global attainment for your research

- Article availability in different formats (Pdf, E-pub, Full Text)

- Endless customer service

- Reasonable Membership services

- Reprints availability upon request

- One step article tracking system 